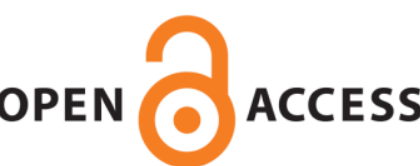

OPEN ACCESS

UWS Academic Portal

\title{
Responsible tourism as a strategic marketing tool for improving the negative image of South Africa
}

George, Richard

Published in:

Worldwide Hospitality and Tourism Themes

DOI:

10.1108/WHATT-07-2017-0031

Published: 09/10/2017

Document Version

Peer reviewed version

Link to publication on the UWS Academic Portal

Citation for published version (APA):

George, R. (2017). Responsible tourism as a strategic marketing tool for improving the negative image of South Africa. Worldwide Hospitality and Tourism Themes, 9(5), 543-554. https://doi.org/10.1108/WHATT-07-20170031

\section{General rights}

Copyright and moral rights for the publications made accessible in the UWS Academic Portal are retained by the authors and/or other copyright owners and it is a condition of accessing publications that users recognise and abide by the legal requirements associated with these rights.

Take down policy

If you believe that this document breaches copyright please contact pure@uws.ac.uk providing details, and we will remove access to the work immediately and investigate your claim. 
Responsible tourism as a strategic marketing tool for improving the negative image of South Africa

\begin{tabular}{|r|l|}
\hline Journal: & Worldwide Hospitality and Tourism Themes \\
\hline Manuscript ID & WHATT-07-2017-0031 \\
\hline Manuscript Type: & Article \\
\hline Keywords: & $\begin{array}{l}\text { Tourism, Sustainability, South Africa, Responsible Tourism, Destination } \\
\text { Image }\end{array}$ \\
\hline \multicolumn{2}{|l}{} \\
\hline
\end{tabular}

SCHOLARONE $^{\text {Ix }}$

Manuscripts 


\title{
Responsible tourism as a strategic marketing tool for improving the negative image of South Africa
}

\begin{abstract}
Purpose - The purpose of this article is to examine the effect of a destination positioning itself as a responsible tourist destination to improve its image.

Design/methodology/approach - A review of the literature pertaining to responsible tourism management, crime-risk and destination image.

Findings - This paper observes that responsible tourism policy can help improve the image of destination South Africa.

Practical Implications - This paper provides recommendations for destinations impacted by negative global perception or being seen as a risky area to travel to in the context of crime.

Originality/value - This paper examines the link between responsible tourism management to counter the negative image of crime-risk in South Africa. In general, there is a dearth of research on this association.

Keywords Tourism, Sustainability, South Africa, Responsible Tourism, Destination Image Paper type: Case study

\section{Introduction}

Since the democratic political elections in 1994, South Africa has been plagued by a reputation for being one of the most dangerous countries in the world (George, 2003). It has one the world's highest crime rates, and in recent years its African National Congress (ANC) government has been engulfed in accusations of corruption and cronyism (Laing and Mahr, 2017). These factors have negatively impacted on international tourist arrivals to the country which has much to offer in terms of wildlife, adventure tourism activities, and heritage and cultural tourism attractions. Despite these setbacks, over the last decade or so, South Africa has been one of the leaders in promoting responsible tourism and is considered at the forefront of practicing responsible and sustainable tourism initiatives.

The objective of this paper is to review the literature on South Africa's responsible tourism strategy and the possible positive implications associated with it to counter the country's perceived negative image as unsafe holiday destination. The review focuses on responsible tourism management (RTM) and destination image.

What is 'responsible tourism' and how does it fit in with other 'sustainable tourism' terms? Increased attention, academic research and literature in the field of responsible management, sustainable development and related topics have led to the emergence of a plethora of definitions in the field. The concept underlying responsible tourism is to provide a superior holiday experience for visitors and improve business opportunities for the tourism sector (Responsible Tourism Manual for South Africa, 2002). The objectives of this approach are to increase the socio-economic benefits to local communities, include a broader spectrum of stakeholders in the
\end{abstract}


decision-making process, promote the sustainable use of limited resources, and improve the tourism offering to the consumer (Pender \& Sharpley, 2005: 197). By integrating corporate social responsibility (CSR) practices, responsible tourism management (RTM) ensures that tourism stakeholders are accountable for their actions and behaviours. Thus, the essence of responsible tourism is identifying actors and attempting to alter industry behaviour towards more sustainable development through the assumption that ethical responsibility will supersede self-interest (Bramwell and Lane, 2008).

For the purpose of this paper, the broader concept of RTM - which incorporates most of the underlying principles of the definitions - is shown in Table 1.

Table 1. Definition of responsible tourism terms

\begin{tabular}{|c|c|c|c|}
\hline Term & Definition & Author & Emphasis \\
\hline 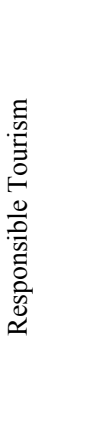 & $\begin{array}{l}\text { Responsible tourism aims to provide a } \\
\text { better holiday experience for guests and } \\
\text { good business opportunities, and better } \\
\text { quality of life for surrounding } \\
\text { communities through increased socio- } \\
\text { economic benefits and improved natural } \\
\text { resource management. }\end{array}$ & $\begin{array}{l}\text { Responsible Tourism } \\
\text { Manual for South } \\
\text { Africa, } 2002 \\
\text { (Spenceley, et al., } \\
\text { 2002) }\end{array}$ & $\begin{array}{l}\text { 1. Develop a competitive } \\
\text { advantage; } \\
\text { 2. Assess, monitor, and disclose } \\
\text { impacts of tourism development; } \\
\text { 3. Ensure involvement of communities } \\
\text { and the establishment of meaningful } \\
\text { economic linkages; } \\
\text { 4. Encourage natural, economic, social, } \\
\text { and cultural diversity; } \\
\text { 5. Promote the sustainable use of local } \\
\text { resources. }\end{array}$ \\
\hline 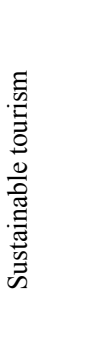 & $\begin{array}{l}\text { Sustainable tourism means achieving a } \\
\text { particular combination of numbers and } \\
\text { types of visitors, the cumulative effect of } \\
\text { whose activities at a given destination, } \\
\text { together with the actions of the servicing } \\
\text { businesses, can continue into the } \\
\text { foreseeable future without damaging the } \\
\text { quality of the environment on which the } \\
\text { activities are based. }\end{array}$ & Middelton, 1998: ix & $\begin{array}{l}\text { The responsible management of } \\
\text { resources for the use and enjoyment of } \\
\text { present and future generations. } \\
\text { Emphasis is placed on managing the } \\
\text { three areas of social, environmental, and } \\
\text { financial impacts of tourism. }\end{array}$ \\
\hline 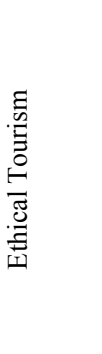 & $\begin{array}{l}\text { Ethical tourism is a concept that goes } \\
\text { beyond the three principles of } \\
\text { sustainability (economic, social and } \\
\text { environmental). It recognises that tourists } \\
\text { and tourism providers must take some } \\
\text { responsibility for their behaviour and } \\
\text { attitudes, with each stakeholder group } \\
\text { gaining equity in the tourism decision- } \\
\text { making process. }\end{array}$ & Weeden, 2002 & $\begin{array}{l}\text { Tourists and tourism providers have a } \\
\text { moral responsibly for their actions. }\end{array}$ \\
\hline 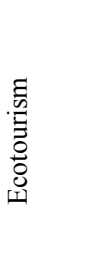 & $\begin{array}{l}\text { Travelling to relatively undisturbed or } \\
\text { uncontaminated natural areas with the } \\
\text { specific objective of studying and } \\
\text { enjoying the scenery and its fauna and } \\
\text { flora, as well as any existing cultural } \\
\text { manifestations (both past and present) } \\
\text { found in these areas. }\end{array}$ & $\begin{array}{l}\text { Ceballos - Lascurain, } \\
\text { 1983, (as cited in } \\
\text { Fennell, 2001) }\end{array}$ & $\begin{array}{l}\text { 1. Provides for environmental } \\
\text { conservation, } \\
\text { 2. Includes meaningful community } \\
\text { participation, } \\
\text { 3. Is profitable and can sustain itself. }\end{array}$ \\
\hline
\end{tabular}


RTM is necessary for a sustainable tourism industry, and can be profitable for businesses. It is imperative that the private, public and voluntary sectors recognise how individual and societal objectives can be aligned in order to achieve a representative, sustainable tourism industry.

\section{Responsible tourism trends}

During the last decade, the concept of responsible tourism has received considerable attention from academic researchers (Mihalic, 2016). In the global business sector, CSR, corporate social investment (CSI), and ethical management practices have emerged as strong trends. Since the Brundtland Report of 1987 (UN, 1987) proposed that intergenerational equality would not be achieved unless the impacts of economic activity on the environment were managed, both debate and research into sustainable tourism practices and philosophies have increased. Concern for sustainable tourism arose from the realisation that mass tourism could have significant negative environmental impacts in destinations if it was not controlled (Budeanu, 2005; Spenceley, 2005).

According to research conducted by the Center for Responsible Travel (CREST) (2017), there is strong evidence that responsible tourism contributes to the bottom line of both businesses and destinations, and the opinions of numerous experts, supported by research are referred to. The Business Case for Responsible Tourism, for example, shows that increasing numbers of businesses are creating environmental departments, adopting environmental and social good practices, seeking certification, and looking at ways to 'green' their supply chain. In the current business climate, it is clear that responsible management practices can lead to bottom-line 
economic gains and can be used to build a strategic advantage (Kotler, Roberto and Lee, 2002: 8; Porter and Kramer, 2006).

There are three main reasons why it has become important for the tourism industry to adopt responsible tourism practices. These are as follows:

\section{i. International trends}

Increased pressure from activist groups and individuals such as Greenpeace as well as the obvious effects of climate change have led to a rise in global CSR awareness (Kolk and van Tonder, 2010). South Africa needs to stay abreast of these international changes if it wants to remain competitive as a country (RTMSA, 2002; King, 2002).

\section{ii. Consumer demand}

Consumers in general are demanding more 'responsible' products and transparency from organisations. There has been a marked increase in public awareness of product supply chains means the demand for ethical goods is growing (www.fairtrade.org.uk), and research shows clearly that brand equity and loyalty increase with effective CSR. RTM is, therefore, demanddriven (Goodwin and Francis, 2003).

\section{iii. Increased business opportunities}

The tourism industry has seen an international trend away from mass products to more personalised experiences. Respect for local culture and heritage, development of local skills, and increased involvement by the local community in tourism development has led to more authentic and unique experiences which, in turn, enables more stakeholders to participate in the tourism sector.

\section{The tourism industry and social responsibility}

Tourism, perhaps more than any other industry, has an obvious interest in adopting socially responsible principles, given its high dependency on cultural heritage and the sustained beauty of natural resources. Research carried out in Istria, Croatia showed that tourists find the 'preservation of nature' as very important (Pavia, Gržinić, and Floričić, 2014: 281).

In recent years, increasing attention has been focused on protecting and enhancing environmental and social sustainability within entire tourism destinations, and not simply within individual businesses. Tools for measuring and criteria for certifying 'green' destinations are gradually being developed, including by United Nations World Tourism Organization (UNWTO), the European Union, National Geographic's Geotourism Program, Ethical Traveler, EarthCheck, Green Globe, and Sustainable Travel International's STEP program. In November 2013, the Global Sustainable Tourism Council (GSTC) released its Criteria for Destinations (GSTC-D), which represents a common understanding of what constitutes the minimum requirements for a sustainable tourist destination.

Lord Marshall, former Chairman of British Airways (BA), defined the travel industry as being 'essentially the renting out of short-term lets of other people's environments'. This definition implies that there is a cost associated with making use of a particular environment. This cost 
should reimburse the host nation for any negative impacts created by the tourist (Keyser, 2015: 396). RTM acknowledges these costs, and tries both to reduce them and to compensate the host nation. Costs are decreased by minimising negative impacts such as labour exploitation and overuse of natural resources. Benefits, on the other hand, are maximised by involving the local community in tourism, and thereby creating income-generating opportunities (Allen and Brennan, 2004: 7). Furthermore, from a social perspective, the New Partnership for Africa's Development's (NEPAD) Tourism Action Plan states that "tourism is recognised as one of the sectors with the most potential to contribute to the economic regeneration of the continent, particularly through the diversification of African economies" (Rogerson and Visser, 2004: 3).

\section{Tourism in South Africa}

Tourism in Africa was historically first developed 'by colonialists for colonialists' and only recently is tourism seen as a development tool (Scheyvens, 1999; Rogerson and Visser, 2004: 2). During the apartheid years (1948 to 1990) tourism was 'non-developmental', leading to a nonrepresentative distribution in product ownership. In the past, most black South Africans did not participate in, nor benefit from the formal tourism sector. This has led to a large proportion of the community not having a stake in the ownership of the national tourism product, leading to misrepresentation and hostility towards the sector (Allen and Brennan, 2004: 9). In 2005, the tourism Black Economic Empowerment (BEE) Charter and Scorecard, a National Department of Tourism (NDT) initiative was formed to promote the rate of transformation in the South African tourism industry. Companies were encouraged to address management areas of ownership, strategic representation, employment equity, skills development, preferential procurement, enterprise development and corporate social investment. This would then lead to BEE accreditation and subsequent government tenders.

Tourism is clearly an important sector contributing considerably to the South African economy. Multi-stakeholder inclusion in tourism development, however, has not always been the norm in the country; and still today various obstacles present themselves in building a truly representative tourism sector. Besides the South African imperative to reduce inequality, tourism, perhaps more so than any other industry, has an obvious interest in following socially responsible principles as it is highly dependent on cultural heritage and the sustained beauty of natural resources (Dolnicara and Leisch, 2008).

Tourism is arguably the largest industry in the world. Moreover, tourism is a highly diverse and labour-intensive sector; currently, one in 22 employed people in South Africa work in the tourism industry, representing 4, 5\% of the total workforce. In fact, tourism in South Africa surpasses mining as an employer (StatsSA, 2016) (see Figure 1). The South African mining industry employed about 462000 individuals in 2015 (StatsSA, 2016). Tourism, therefore, can play an important role in addressing poverty, inequality, and unemployment in the developing world (Rogerson and Visser, 2004: 4).

Figure 1. Tourism and jobs in South Africa. Source: StatsSA, 2017. 


\section{Tourism and employment in South Africa}

Key findings from Tourism Satellite Account for South Africa, 2015

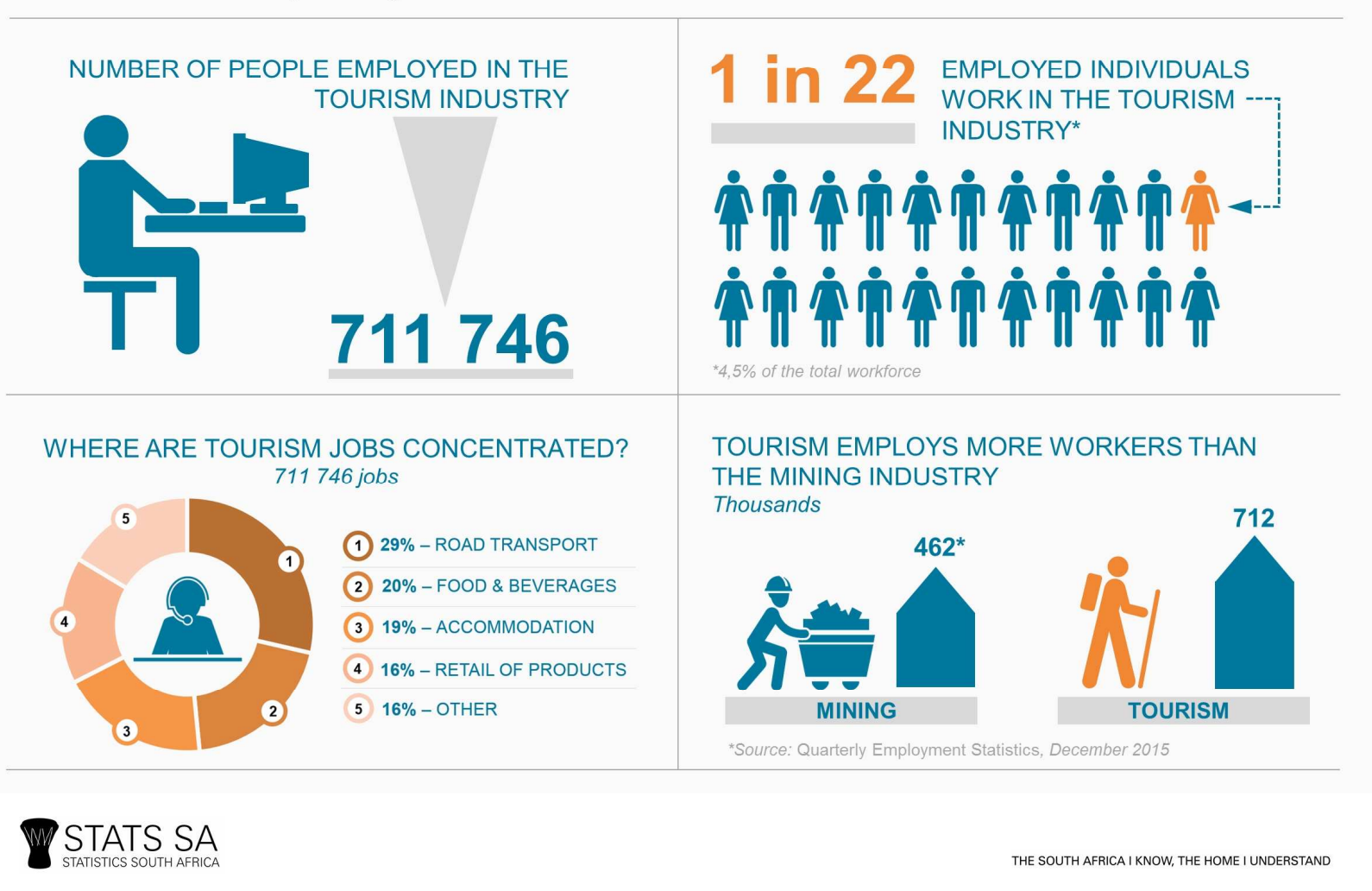

In 2015, 8, 9 million international foreign tourists visited South Africa (SA Tourism, 2016). A variety of pull factors, such as excellent value for money (against all major currencies), heritage and culture, wine farms, edu-tourism, health tourism, community-based tourism, in addition to the 4Ss (sun, sand, sea, safaris), make for South Africa a very attractive holiday destination. However, the threat of negative perceptions of a destination being formed by potential tourists to South Africa can come from the risk of safety due to crime and political instability as well as less obvious factors such as health issues (i.e. malaria, typhoid and yellow fever). In 2015, South Africa experienced an increase in violent crimes, political instability, xenophobic attacks and repetitive social-and labour unrest. Furthermore, South African tourist arrivals statistics for 2015 showed significant declines over the previous year (Ferreira and Perks, 2017).

\section{Responsible tourism research}

Most studies on responsible tourism have been conducted on the perspectives of tourists or services providers (e.g. Tearfund, 2002; Spenceley, 2006; Van der Merwe and Wocke, 2007, Frey and George, 2010). For example, Spenceley (2006) replicated the 2001 Tearfund study to evaluate to what extent South African tour operators were engaging in responsible management practices. 
Spenceley surveyed a sample of 20 South Africa small-sized tour operators. The survey included questions on partnerships, local benefits, training, policies, and consumer demand for responsible tourism. The study found that $66 \%$ of tour operators claimed that responsible tourism initiatives positively impacts local communities. These took the form of employment creation, using local service providers and purchasing local products (Spenceley, 2007: 3). However, the research also found that tour operators faced numerous barriers in bringing benefits to local people. Concerns about crime, accessibility and problems relating to skills, consistent service quality and language capacity were raised. Further, Frey and George (2010) studied RTM in terms of tourism business owners' perspectives. Their study revealed that despite general positive attitude towards responsible tourism initiatives, businesses were not investing time and money to follow RTM practices.

Van der Merwe and Wöcke (2007) researched the level of responsible tourism practices in the South African hotel sector. The aim of the study was to uncover the level of understanding regarding CSR and the extent to which practices from the Responsible Tourism Guidelines (NDT, 2002) were being implemented. The study found that, on average, South African hotels were implementing $47 \%$ of the economic guidelines, $45 \%$ of the social elements and $40 \%$ of the guidelines were encouraging general responsible behaviour. A high percentage of the sample did not use CSR in their marketing campaigns and had not set any measurable targets (Van der Merwe and Wöcke, 2007). The research sample included a significant number of hotels that belong to associations promoting responsible tourism (such as Fair Trade in Tourism South Africa) or had participated in the Imvelo Responsible Tourism Awards. Despite the potentially elevated figures these associations would bring, the results of both studies indicate low levels RTM practices.

Paul and Sreejesh (2017) examined how responsible tourism affects local communities' perceptions of sustainability and in turn perceptions of their quality of life. The study was conducted on 432 residents from three tourism destinations in India. The findings revealed that local residents' favourable perception of responsible tourism practices have a significant positive relation with the sustainability of the destination in terms of (economic, environmental, social and cultural) perceived by the local community, and quality of life of community (community wellbeing, emotional wellbeing and health and safety well-being).

\section{Responsible tourism in South Africa}

The first Conference on Responsible Tourism on was hosted in Cape Town in 2002 prior to the World Summit on Sustainable Development (WSSD) held in Johannesburg that same year. The Conference on Responsible Tourism led to the 'Cape Town Declaration' where responsible tourism was defined as a 'three-tiered approach': firstly, tourism development should increase the quality of life for surrounding communities; secondly it should create better business opportunities; and thirdly, improved experiences for tourists. Fundamental to this approach is the co-operation of communities and the public and private sector. Globally, South Africa's responsible tourism initiatives were seen as progressive. However, fifteen years later, the question is increasingly being asked to what extent the Cape Town Declaration and the Responsible Tourism Guidelines (NDT, 2002) have been adopted by the industry and have led to revised management practices. The Eight International Conference on Responsible Tourism in 
Destinations (RTD8) hosted in Manchester, UK in 2014 highlighted the need for increased government and private sector commitment to responsible tourism implementation, the lack of good measurement systems for impact assessment and the necessity for the debate to move towards addressing responsible tourism in a more strategic rather than moralistic manner.

The National Tourism Sector Strategy (NTSS) calls on the National Department of Tourism (NDT) and other stakeholders to promote sustainable and responsible tourism to make South Africa a tourism destination of choice. In March 2002, the NDT published the Responsible Tourism Guidelines for South Africa (RTGSA), which was followed up in July 2002 with The Responsible Tourism Manual for South Africa (RTMSA). Both documents aim to provide tourism businesses and community-based tourism enterprises (CBTEs) with information and opportunities that responsible tourism presents for improving business performance. Both documents in no uncertain terms outlined that for South Africa, responsible tourism was not a luxury but a necessity. Specific to South Africa, and in line with current international best practice, the authors of The Responsible Tourism Manual for South Africa have collected a range of practical and costeffective responsible actions available to tourism businesses and tourism associations. The manual refers to many useful sources of information and examples of best practice that can help to guide users' implementation of responsible business activities.

The NDT launched the National Tourism Sector Strategy (NTSS) 2010 to 2020. The NTSS is a blueprint for the tourism sector in South Africa. The strategy aims to increase responsible growth of the South African tourism industry from 2010 to 2020. The objectives of the NTSS are as follows:

- To provide national guidelines for the development and implementation of responsible tourism;

- To create a national framework for development and implementation of norms and standards for responsible tourism;

- To harmonise implementation of responsible tourism at provincial and local government levels;

- To coordinate the National Department of Tourism's (NDT) approach towards tourism sustainability;

- To identify opportunities for community participation in tourism; and

- To guide strategy development and alignment for tourism development and management in both the public and private sectors.

Figure 2. illustrates how the National Responsible Tourism Strategy (NRTS) is embedded into the country's National Tourism Sector Strategy (NTSS).

Figure 2. The National Tourism Sector Strategy. Source: https://www.tourism.gov.za 


\section{Destination Image}

Image is often taken for reality in the tourism industry. For instance, a tourist might perceive that a destination is an unsafe and a dangerous place to visit. In recent years, for example, Mexico's drug-related crime has negatively affected its image. The reality may well be that holiday resorts and cities in Mexico are no more dangerous than any other destination around the world. Nevertheless, the prospective visitor to Mexico might change his or her plans as a result of these negative perceptions. 'Place images' can be very influential in destination choice decisionmaking. If a destination is portrayed in a particular way (perhaps through popular culture media such as television programmes, movies or contemporary novels), there may be an immediate effect on the destination. Small-scale destinations, for example, that receive positive media coverage (i.e. a visit by a Hollywood celebrity) may find themselves besieged by visitors in the peak tourist season (Connell, 2005: 763).

All destinations have images. Some of these images are based on the destination's geography, standard of living, people, infrastructure, climate and other natural attractions. Other images are based on the cost, ambience, history, cleanliness, and safety and security of the destination. Images may be good, bad or indifferent. Generally speaking, images can be either descriptive (for example, the perception that Blackpool (a seaside town in the north-west of the UK) is a 
family-holiday coastal resort) or evaluative (for example, the perception that Blackpool is tacky, dirty and unsafe).

Images are believed to develop on two levels: organic (formed internally as a result of actual experience or visitation) and induced (formed externally from advertisements, publicity, news reports, or input from acquaintances (Gartner, 1989; Gunn, 1972). Media coverage of occurrences of serious acts of crime at a destination (involving tourists or locals) has the potential to shape the induced image individuals have of destinations. Negative media coverage can, thus, impact attitude formation quite easily. Image therefore, becomes a crucial factor in travel choice and tourism marketing (Chon, 1991; Dann, 1996; Echtner and Ritchie, 1991). Although the importance of image to marketing is well documented, the impact of touristoriented crime and violence on destination image has received scant attention. A comprehensive review of the literature on destination image, although without reference to the effects of crime and violence, confirms that it is a critical component in the tourist's destination process (Baloglu, 1997; Chon, 1991; Dann, 1996; Walmsley and Young, 1998).

\section{Conclusion}

Thus, exists a yin-and-yang philosophy to South Africa's image as an international tourist destination: on the one hand the country is tarnished by its image as being an unsafe place to visit; on the other hand, it is a leading destination in terms of sustainability where tourism is seen as a tool for improving its previously disadvantaged citizens' lives. However, to what extent does one offset the other? Unfortunately, South African tourism authorities (as are most countries' police and tourism services) are hampered by a lack of data on crime, especially crime targeting tourists (Bloom, 1996). In addition, researchers are unable to forecast how many tourists are not visiting the country due to fear of crime; most of this evidence is merely anecdotal (such as: "I wouldn't go there; isn't it dangerous?" Likewise, having a responsible tourism policy in place does not guarantee increased tourist numbers; researchers and practitioners do not know how many foreign tourists are visiting the country because of the industry's perceived to-be-good ethical practices; this would be virtually impossible to establish. Being 'responsible' could also be construed as the tourism industry itself being committed to providing safety and security for tourists. Most of the existing research on responsible tourism has taken the perspectives of the consumer, service providers or the local destination communities. More research is required into the extent in which responsible tourism policies implemented by destinations influence consumers' negative perceptions.

\section{References}

Allen, G. and Brennan, F. (2004), Tourism in the New South Africa-Social Responsibility and the Tourist Experience, I. B. Tauris, New York.

Ashley, C. and Roe, D. (2002), "Making tourism work for the poor: strategies and challenges in southern Africa“, Vol. 19 No. 1, pp. 61-82. 
Baloglu, S. (1997), "The relationship between destination images and sociodemographic and trip characteristics of international travelers", Journal of Vacation Marketing, Vol. 3 No. 3, 221-233.

Bloom, J. (1996), "A South African perspective of the effects of crime and violence on the tourism industry", in Pizam, A. \& Mansfeld, Y. (Eds), Tourism, Crime and International Security Issues, John Wiley \& Sons, Chichester, pp. 95-102.

Bramwell, B., Lane, B., McCabe, S., Mosedale, J. and Scarles, C. (2008), "Research perspectives on responsible tourism", Journal of Sustainable Tourism, Vol. 16 No. 3, pp. 253-257.

Budeanu, A. (2005), “Impacts and responsibilities for sustainable tourism: a tour operator's perspective", Journal of Cleaner Production, Vol. 13 No. 2, pp. 89-97.

Center for Responsible Travel (CREST). (2017), available at: www.responsibletravel.org/ (accessed 2 July 2017).

Chon, K.S. (1991), "Tourism destination image modification process: marketing implications", Tourism Management, Vol. 12 No. 1, 68-72.

Connell. J. (2005), “Toddler, tourism and Tobermory: destination marketing issues and television-induced tourism", Tourism Management, Vol 26 No. 5.

Dann, G. (1996), “Tourists' images of a destination: an alternative analysis”, Journal of Travel \& Tourism Marketing, Vol. 5 No. 12, 41-55.

Dolnicara, S. and Leisch, F. (2008), "Selective marketing for environmentally sustainable tourism”, Tourism Management, Vol. 29 No. 4, pp. 672-680.

Echtner, C.M. and Ritchie, J.R.B. (1991), "The meaning and measurement of destination image", Journal of Tourism Studies, Vol. 2 No 2, 2-12.

Fennell, D. (2001), “A content analysis of ecotourism definitions”, Current Issues in Tourism, Vol. 4, No 5, pp. 403-421.

Ferreira, D. and Perks, S. (2017), "The role of democratic peace and diplomatic governance in increasing South Africa's tourism demand”, Conference paper 2017. Annual South Africa Business Conference, Cape Town, May 2017.

Frey, N. and George, R. (2010), "Responsible tourism and the tourism industry: the missing link between business owners' attitudes and behaviour in the Cape Town tourism industry", Tourism Management, Vol. 3 No. 5, pp. 621-628.

Gartner, W.C. (1993), "Image formation process", Journal of Travel and Tourism Marketing, Vol. 2 No. $2 / 3$. 
George, R. (2003), “Tourists' perceptions of safety and security while visiting Cape Town”, Tourism Management, Vol. 24. No. 5, pp. 575-585.

Goodwin, H. and Francis, J. (2003), "Ethical and responsible tourism: consumer trends in the UK", Journal of Vacation Marketing, Vol. 9 No. 3, pp. 271-284.

Gunn, C. (1972), "Vacationscape: designing tourist regions", Bureau of Business Research, Austin: University of Texas Press.

Keyser, H. (2015), "Managing tourism responsibly", in George, R. (Ed). Managing Tourism in South Africa, $2^{\text {nd }}$ edn. Oxford University Press, Cape Town, pp. 393-416.

King, J. (2002), "Destination Marketing Organisations: Connecting the experience rather than promoting the place", Journal of Vacation Marketing, Vol. 8 No. 2, 105-108.

Kolk, A. and van Tulder, R. 2010. "International business, corporate social responsibility and sustainable development”, International Business Review, Vol. 29 No. 2, 119-125.

Kotler, P. and Roberto, E. (1989), Social Marketing: Strategies for Changing Public Behaviour, The Free Press, Macmillan, New York.

Kotler P, Roberto, N. and Lee, N. (2002), Social Marketing: Improving the Quality of life. $2^{\text {nd }}$ edition. Sage Publications, California.

Krippendorf, J. (1987), The Holiday Makers: Understanding the Impact of Leisure and Travel, Butterworth-Heinemann, Oxford.

Laing, A and Mahr, K (2017), 'Corrupt, divided ANC must cleanse itself, says Zuma'. The Times Saturday July 1, p. 46.

Middleton, V.T.C. (1988), Marketing and Travel and Tourism, Butterworth-Heinemann, Oxford.

Mihalic, T. 2016. "Sustainable-responsible discourse - Towards 'responsible' tourism”, Journal of Cleaner Production, Vol. 111, pp. 461-470.

National Department of Tourism (NDT). (1996), "White paper: development \& promotion of tourism in South Africa". Pretoria: NDT.

National Department of Tourism (NDT). (2002), "Responsible Tourism Guidelines", available at: http://www.info.gov.za/ (accessed 9 July 2017).

National Department of Tourism (NDT). (2005), "Tourism BEE Charter and Scorecard”, available at: http://www.info.gov.za/ (accessed 9 July 2017). 
Paul, V.M. and Sreejesh, S. (2017), "Impact of responsible tourism on destination sustainability and quality of life of community in tourism destinations", Journal of Hospitality and Tourism Management, Vol. 31, pp. 83-89.

Pavia, N., Gržinić, J. and Floričić, T. (2014), "The Perception of Gastronomic Events within the Framework of Sustainable Tourism Development", in Brebbia, C.A., Favro, S. and Pineda, F.D., (Eds), Sustaible Tourism VI, Witt Press, Southampton, UK. pp. 277-289.

Pender, L. and Sharpley, R. (2005), The Management of Tourism. Sage Publications, London.

Porter, M. and Kramer, M. (2006), "Strategy and society: the link between competitive advantage and corporate social responsibility", Harvard Business Review, Vol. 84 No. 12, pp. 78-89.

Rogerson, M. and Visser, G. (2004), Tourism and Development issues in Contemporary South Africa, Africa Institute of South Africa, Pretoria.

Rothschild, M. (1999), "Carrots, sticks, and promises: a conceptual framework for the management of public health and social issue behavior", Journal of Marketing, Vol. 63, pp. 2437.

Scheyvens, R. (1999), "Ecotourism and the empowerment of local communities", Tourism Management, Vol. 20 No. 2, pp. 245-249.

South African Tourism. (2016), 2015 Annual Tourism Performance Report. SA Tourism Strategic Research Unit, Johannesburg.

Spenceley, A. (2005), "Nature-based tourism and environmental sustainability in South Africa", Journal of Sustainable Tourism, Vol 13 No. 2, pp. 136-144.

Spenceley, A. (2007), 'Responsible tourism practices by South African tour operators', International Centre for Responsible Tourism - South Africa. http://anna.spenceley.co.uk/Papers.htm

Spenceley, A. (2008), Tourism, Communities and the Environment in Southern Africa, CABI, London.

Spenceley, A., Relly, P., Keyser, H., Warmeant, P., McKenzie, M., Mataboge, A. Norton, P., Mahlangu, S. and Seif, J. (2002), Responsible Tourism Manual for South Africa, Department of Environmental Affairs and Tourism, Pretoria, South Africa.

Statistics South Africa (StatsSA). (2017), Tourism: jobs, the economy and spending", available at: http://www.statssa.gov.za/?p=9264 (accessed June 30 2017). 
Tearfund. (2001), "Tourism: Putting ethics into practice - a report on the responsible business practices of 65 UK-based tour operators", available at: www.tearfund.org/ (accessed June 5 2017).

Tearfund. (2002), "Worlds apart: a call to responsible global tourism”, available at: www.tearfund.org (accessed May 19 2017).

United Nations (UN). (1987), "The Brundtland Report", available at: www.un.org/ (accessed August 12 2016).

United Nations World Tourism Organisation (UN-WTO). (2017), available at www.worldtourism.org/ (accessed July 2017).

Van der Merwe, M. and Wöcke, A. (2007), “An investigation into responsible tourism practices in the South African hotel industry", South African Journal of Business Management, Vol. 38 No. 2, pp. 1-15.

Walmsley, D.J. and Young, M. (1998), "Evaluative images and tourism: the use of personal constructs to describe the structure of destination images", Journal of Travel Research, Vol. 38 No. 2, 65-69.

Weeden, C. 2002. "Ethical tourism: an opportunity for competitive advantage", Journal of Vacation Marketing”, Vol. 8 No. 2, pp. 141-153.

\section{Further reading/browsing}

Bramwell, B., Lane, B., McCabe, S., Mosedale, J. and Scarles, C. (2008), "Research perspectives on responsible tourism”, Journal of Sustainable Tourism, Vol. 16 No. 3, pp. 253-257.

Center for Responsible Travel (CREST), available at: www.responsibletravel.org.

Spenceley, A. (2008), Tourism, Communities and the Environment in Southern Africa, CABI, London. 